\title{
The Ethical Reporting of Non-GAAP Performance Measures
}

Ervin L. Black

Director, Steed School of Accounting, Full Professor and W.K. Newton Chair of Accounting Price College of Business, University of Oklahoma. E-mail: ervblack@ou.edu

Generally accepted accounting principles (GAAP) provide for a standardized method of calculating various performance measures, such as net income, income from continuing operations, and cash flow from operations. There are two primary sources of GAAP the International Financial Reporting Standards (IFRS), as developed by the International Accounting Standards Board (IASB), and the U.S. GAAP, as developed by the Financial Accounting Standards Board (FASB). However, non-GAAP performance measures have been repor- ted by companies for several decades, as an alternative to these GAAP measures. Managers argue that these non-GAAP measures improve the information about the core earnings of their companies. Company managers have discretion in determining what is included and what is not included in the calculation of these non-GAAP performance measures. In this essay, I review non-GAAP reporting, make a call for the ethical reporting of non-GAAP performance measures, and make recommendations for ways to improve non-GAAP reporting.

\section{REVIEW: NON-GAAP REPORTING}

Since 2001, the U.S. Securities and Exchange Commission (SEC) has expressed concern about the potential for non-GAAP earnings disclosures to mislead investors (Dow Jones \& Company, 2001; Securities and Exchange Commission, 2001a, 2001b). While non-GAAP earnings figures may not be credible to all financial statement users, prior research suggests that some stakeholders rely heavily on non-GAAP earnings (Frederickson \& Miller, 2004; Elliot, 2006; Bhattacharya, Black, Christensen, \& Mergenthaler, 2007). In 2010, Howard Scheck, Chief Accountant at the SEC's Division of Enforcement, identified non-GAAP earnings metrics as a fraud risk factor (Leone, 2010). In July 2013, the SEC formed a taskforce to scrutinize companies' non-GAAP earnings metrics that could potentially be misleading "with an eye toward possible enforcement cases" (Rapoport, 2013). In addition, aggressive non-GAAP reporting is now one of the top five reasons for the SEC comment letters (Ernst \& Young, 2012).

In response to fears that companies could use non-GAAP earnings disclosures to mislead investors, the SEC issued a warning to investors about the potential dangers of relying on pro forma earnings figures in December 2001. Then, in July 2002, the Sarbanes-Oxley Act became law, prohibiting the use of non-GAAP earnings to mislead investors in any way. Moreover, as a part of the 2002 Sarbanes-Oxley Act (SOX), the U.S. Congress directed the SEC to issue regulations to implement these rules. Subsequently, the SEC issued Regula- tion G, which became effective in early 2003. The SEC Rule 33-8176 defines a non-GAAP financial measure as follows:

Definition of Non-GAAP Financial Measure: numerical measure of a registrant's historical or future financial performance, financial position or cash flows that includes amounts that are not part of the most directly comparable GAAP measure or excludes amounts that are part of the most directly comparable GAAP measure.

Non-GAAP reporting has also been an area of attention internationally. In 2002, the International Organization of Securities Commissions (IOSCO) issued a release to alert and caution investors and other users of financial statements about non-GAAP earnings disclosures (International Organization of Securities Commissions, 2002) . More recently, Hans Hoogervorst, chairman of the IASB, in a panel discussion at the Accounting \& Finance/IFRS Research Forum, indicated his willingness to consider additional standard setting on non-GAAP performance reporting. In addition, in 2014, IOSCO issued a proposed statement, patterned soon after on the use and presentation of non-GAAP financial measures, stating that:

Non-GAAP financial measures can be useful to issuers and investors because they can provide additional insight into an issuer's financial performan- 
ce, financial condition and/or cash flow. The use of non-GAAP financial measures also can provide issuers with flexibility in communicating useful, entity-specific information. Problems can arise, however, when non-GAAP financial measures are presented inconsistently, defined inadequately, or obscure financial results determined in accordance with GAAP. Furthermore, non-GAAP financial measures typically lack a standardised meaning and thus are generally not comparable from one issuer to the next (International Organization of Securities Commissions, 2014).

In a recent article published by The New York $\mathrm{Ti}$ mes, it is informed that 334 companies in the Standard \& Poor's 500-stock index reported non-GAAP earnings last year, up from 232 such companies in 2009. The dollar amount of cost adjustments made to those companies' profits totaled $\$ 132$ billion last year, more than double the amount in 2009 (Morgenson, 2015). Prior research debates whether these 'manager-customized' earnings provide investors with a clearer picture for forecasting future operating performance (not conveyed by GAAP earnings) or simply portray an overly optimistic depiction of performance (Bhattacharya, Black, Christensen, \& Larson 2003; Curtis, McVay, \& Whipple, 2014). This skepticism about non-GAAP reporting stems from the fact that these earnings disclosures are not audited, therefore, allow managers increased discretion in providing non-standard performance metrics.

As an example of the extreme nature of some of these non-GAAP disclosures, recently one company provided 11 different non-GAAP financial measures. This company presents the following financial measures to supplement its Consolidated Financial Statements, which are prepared in accordance with the IFRS. These measures are designed to measure growth, capital efficiency, cash and profit generation, and optimization of XYZ's capital structure:

- Orders and order backlog;

- Adjusted or organic growth rates of revenue and orders;

- Book-to-bill ratio;

- Total sectors profit;

- Return on equity (ROE) (after tax);

- Return on capital employed (ROCE) (adjusted);

- Free cash flow (FCF);

- Adjusted EBITDA, adjusted EBIT, and adjusted EBITDA margins;

- Earnings-effects from purchase price allocation (PPA);

- Net debt; and

- Adjusted industrial net debt.

\section{ETHICAL REPORTING OF NON-GAAP FINANCIAL MEASURES}

Black, Black, Christensen, and Heninger (2012) found that non-GAAP reporting in the U.S. is generally viewed in a more positive light in the post-Sarbanes Oxley legislation period, after the implementation of Regulation G. In addition, investors seem to be able to distinguish some types of aggressive reporting and discount these firms on the stock market. Further, our results imply that earnings regulation may have increased the average quality of non-GAAP earnings disclosures by filtering out misleading disclosures.

Managers have a menu of choices from which they can choose to influence stakeholder perceptions, and their selection within a given period depends on the relative costs and benefits of each menu choice. If managers can meet their strategic objectives based on neutral reporting of solid operating performance, then they have no need to manage GAAP earnings or report non-GAAP earnings to alter stakeholder perceptions. However, operating performance alone does not enable companies to meet or beat earnings targets, then mana- gers can use the discretion allowed within GAAP to influence the reporting of current performance with their available menu choices, such as real earnings management (e.g. decreasing discretionary spending), accruals management (e.g. managing reserves), classification shifting (McVay, 2006; Fan, Barua, Cready, \& Thomas, 2010; Abernathy, Beyer, \& Rapley, 2014), and expectation management (Matsumoto, 2002). However, sometimes managers' best efforts to manage earnings cannot produce GAAP earnings that meet or beat strategic earnings targets or expectations. It is then that we hypothesize that managers are most likely to turn to non-GAAP reporting.

Black, Christensen, Joo and Schmardebeck (2015) found evidence suggesting that managers prefer to meet expectations based on neutral reporting of solid operational performance. They also found that, conditional on missing analysts' expectations after employing both accruals and real earnings management, firms are 
more likely to report non-GAAP earnings. They report a substitute relation between earnings management and managers' propensity to report earnings and to do so aggressively, even after controlling for past accruals management, current operating performance, prior non-GAAP reporting, and the costs of earnings management.

Managers and analysts also have conference calls in which information is exchanged and expectations about financial performance are made. Black, Christensen, Kiosse and Steffen (2015b) found that managers can influence analysts' street earnings expectations and adjustments through these conference calls.

Given the influence management has on providing financial performance measures, it is imperative that managers exercise this influence in an ethical manner. Non-GAAP financial measures are used by a variety of stakeholder groups, including investors, lenders, employees, compensation committees. Such measures should be developed and provided to these stakeholders so that it is clear for these users to understand and use them in various ways. Non-GAAP numbers may be very beneficial, but they can also be used to manipulate information in order to mask underlying firm performance. To this end, managers need to make sure that adjustments and modifications that are made do not create confusion.

Many financial users are able to distinguish this management attempt to manipulate firm perceptions and, in fact, research has shown that these firms' stock returns are punished (Black \& Christensen, 2009). However, not all investors and other users are able to discriminately determine the usefulness of non-GAAP measures, and small less sophisticated investors are at a disadvantage (Bhattacharya et al., 2007).

Regulation $G$ requires companies that make available non-GAAP financial measures to the public to also provide a clear and understandable reconciliation to the most closely comparable GAAP financial measure. Regulation $G$ is intended to ensure that investors receive adequate information in evaluating a company's use of non-GAAP financial measures. The earnings announcement that provides non-GAAP figures is furnished on Form 8-K and it might provide users with a source of reference for obtaining a company's most recent statements regarding its financial condition. The new rules and amendments are in the public interest and consistent with the protection of investors. In addition, for providing a reconciliation of non-GAAP with GAAP financial measures, the company needs to provide an explanation and statement of purpose for non-GAAP disclosure.

\section{RECOMMENDATIONS FOR NON-GAAP REPORTING}

Unfortunately, there is no Regulation G required or enforceable worldwide. Therefore, it is of paramount importance that international firms that provide non-GAAP disclosure adhere to the spirit and requirements that Regulation $\mathrm{G}$ recommends. There is a long way to ensure that non-GAAP financial reporting is done in a way that makes information useful to various stakeholders.

Nevertheless, this is not enough. Non-GAAP financial measures need to be determined in a way that is not misleading, even if there is full reconciliation and disclosure. The use of non-recurring items as adjustments when preparing a non-GAAP financial measure is a questionable practice, just as the use of a non-GAAP figure to meet a benchmark or target that could not have been met through normal GAAP.

I recommend the following to be done: even though the audit committee is responsible for the audited financial statements, they should also play a role in providing oversight in non-GAAP reporting that a company does to help ensuring that transparent and unbiased non-GAAP disclosure has been provided, which is useful and not misleading to users. This might elevate the importance and monitoring over non-GAAP reporting.

In addition, there is evidence that ethical training is beneficial to improve the behavior of accounting professionals (Black, Burton \& Stocks, 2015). I recommend that ethical training on the preparation and use of non-GAAP financial measures is provided to accounting professionals on an ongoing basis. The SEC keeps having many comment letters related to problems with non-GAAP reporting. They may provide the basis for case studies on the preparation, calculation, and disclosure of non-GAAP performance measures.

In conclusion, I make the following non-GAAP financial reporting recommendations for companies worldwide:

1. Follow the guidelines from the SEC, Regulation G.

2. Avoid the use of recurring items as adjustments for non-GAAP measures.

3. Include audit committee oversight of non-GAAP re- 
porting.

4. Provide training through continuing professional education (CPE) or other means to increase ethical awareness through transparent and unbiased non-GAAP reporting.

\section{REFERENCES}

Abernathy, J. L., Beyer, B., \& Rapley, E. T. (2014). Earnings management constraints and classification shifting. Journal of Business Finance \& Accounting, 41, 600-626.

Bhattacharya, N., Black, E., Christensen, T., \& Larson, C. (2003). Assessing the relative informativeness and permanence of pro forma earnings and GAAP operating earnings. Journal of Accounting and Economics, 36, 285-319.

Bhattacharya, N., Black, E. L., Christensen, T. E., \& Mergenthaler, R. D. (2007). Who trades on pro forma earnings information? The Accounting Review, 82, 581-619.

Black, D. E., Black, E. L., Christensen, T. E., \& Heninger, W. G. (2012). Has the regulation of pro forma reporting in the U.S. changed investors' perceptions of pro forma earnings disclosures? Journal of Business Finance and Accounting, 39, 876-904.

Black, D., \& Christensen, T. (2009). US managers' use of 'pro forma' adjustments to meet strategic earnings targets. Journal of Business Finance \& Accounting, 36, 297326.

Black, E.L., Burton, F.G., \& Stocks, K. (2015). Does education and training in ethics affect the ethical awareness of accountants? An international study (working paper).

Black, E. L., Christensen, T.E., Joo, T., \& Schmardebeck, R. (2015, no prelo). The relation between earnings management and non-GAAP reporting. Contemporary Accounting Research.

Black, E., Christensen, T., Kiosse, P.V., \& Steffen, T.D. (2015a, no prelo). Has the regulation of non-GAAP disclosures influenced managers' use of aggressive earnings exclusions? Journal of Accounting, Auditing \& Finance.

Black, E., Christensen, T., Kiosse, P.V., \& Steffen, T.D. (2015b). Does management discussion of pro forma earnings in press releases and conference calls influence street earnings exclusions? (working paper).

Curtis, A., McVay, S., \& Whipple, B. (2014, no prelo). Non-GAAP earnings: informative or opportunistic? An analysis of transitory gains. The Accounting Review.
Dow Jones \& Company. (2001, 19 de junho). SEC probes 4 firms for possible abuses of pro-forma results. Dow Jones Newswires, 19-22.

Elliott, W. B. (2006). Are investors influenced by pro forma emphasis and reconciliations in earnings announcements? The Accounting Review, 81(1), 113-133.

Ernst \& Young. (2012). SEC comments and trends. Recuperado de http://www.ey.com/Publication/vwLUAssets A L/SECC omments Trends_ CC0421_24September2015/\$FILE/SECCommentsTrends_CC0421_24September2015.pdf

Fan, Y., Barua, A., Cready, W., \& Thomas, W. (2010). Managing earnings using classification shifting: evidence from quarterly special items. The Accounting Review, 85(4), 1303-1323.

Frederickson, J. R., \& Miller, J. S. (2004). The effects of pro forma earnings disclosures on analysts' and nonprofessional investors' equity valuation judgments. The Accounting Review, 79, 667-686.

International Organization of Securities Commissions. (2002, maio). Cautionary statement regarding non-GAAP results measures. Recuperado de https://www.iosco.org/ news/pdf/IOSCONEWS4.pdf

International Organization of Securities Commissions. (2014, setembro). Proposed statement on non-GAAP financial measures. Recuperado de http://www.iosco.org/ library/pubdocs/pdf/IOSCOPD447.pdf

Leone, M. (2010, 29 de setembro). What's on the SEC's radar? CFO.com.

Matsumoto, D. (2002). Management's incentives to avoid negative earnings surprises. The Accounting Review, 77, 483-514.

McVay, S. (2006). Earnings management using classification shifting: an examination of core earnings and special items. The Accounting Review, 81, 501-531.

Morgenson, G. (2015, 30 de outubro). Valeant shows the perils of fantasy numbers. The New York Times. 
Rapoport, M. (2013, 10 de dezembro). SEC task force probes use of non-GAAP metrics: hot technology IPOs have brought more focus to accounting issues. Wall Street Journal.

Securities and Exchange Commission. (2001a, 4 de de- zembro). Press release 2001-144. Washington, DC: SEC.

Securities and Exchange Commission. (2001b, 4 de dezembro). Cautionary advice regarding the use of "pro forma" financial information in earnings releases. Release 33-8039, 34-45124, FR-59. 